\title{
The Effect of Thrombocytopenia on
}

\section{Experimental Arteriosclerotic Lesion}

\section{Formation in Rabbits}

\section{SMOOTH MUSCLE CELL PROLIFERATION AND RE-ENDOTHELIALIZATION}

\author{
Robert J. Friedman, Michael B. Stemerman, Barry Wenz, Sean moore, \\ Jack Gauldie, Michael Gent, Melvin L. Tiell, and Theodore \\ H. SPAET, Department of Medicine, Division of Hematology, \\ Montefiore Hospital and Medical Center, Albert Einstein College of \\ Medicine, Bronx, New York 10467, and Departments of Pathology and \\ Clinical Epidemiology and Biostatistics, McMaster University, Faculty \\ of Medicine, Hamilton, Ontario, Canada
}

\begin{abstract}
A B S T RACT This study was designed to investigate the mechanisms involved in fibromusculoelastic lesion formation produced by selective de-endothelialization by the intra-arterial balloon catheter technique in thrombocytopenic rabbits. Thrombocytopenia was induced and maintained for up to 31 days by daily injections of highly specific sheep anti-rabbit platelet sera (APS). Evidence for re-endothelialization was obtained by i.v. Evans blue dye $30 \mathrm{~min}$ before sacrifice. Rabbits received daily injections of APS, which reduced the mean platelet count to $5,600 / \mathrm{cm}^{3}$; control animals received identically treated normal sheep sera on the same schedule, and had mean daily platelet counts of $363,000 / \mathrm{cm}^{3}$. Evaluation of intimal thickness was assessed by counting cell layers in semithin sections. Intimal thickening in aortae from rabbits treated with APS was strikingly suppressed, in contrast to those from normal sheep sera-treated animals which showed a mean intimal thickness of 18 cell layers within 28 days often after de-endothelialization. Re-endothelialization was not affected by APS treatment. These results indicate that the proliferation of smooth muscle cells which is characteristic of arteriosclerotic lesions is dramatically inhibited by reduction of platelets.
\end{abstract}

Dr. Stemerman is currently Head of Thrombosis and Hemostasis Unit, Beth Israel Hospital, Boston, Mass. 02215.

Received for publication 11 October 1976 and in revised form 20 June 1977.

\section{INTRODUCTION}

A knowledge of the interaction of platelets, smooth muscle cells, and endothelium is of major significance to an understanding of the mechanisms of the arteriosclerotic process. When the endothelium of an artery is removed, medial smooth muscle cells migrate into the intima and subsequently proliferate $(1,2)$. The resulting fibromusculoelastic lesion is considered to be a precursor of the characteristic lesion of atherosclerosis, the fibrous plaque $(3,4)$. Recently, it has been observed that a platelet-derived constituent in serum is required for growth of arterial smooth muscle cells in culture (5). This factor may be involved in initiating and (or) maintaining smooth muscle cell migration or proliferation in vivo. Previously, we have shown that complicated lesions of atherosclerosis caused by repeated aortic intimal injury in rabbits were significantly inhibited by induction of severe thrombocytopenia (6). The purpose of the current study is: (a) to investigate the role of thrombocytopenia induced by purified anti-platelet sera on the smooth muscle proliferation and intimal thickening seen after endothelial removal; (b) to study the effect, if any, of the highly purified antisera on the smooth muscle cell proliferation; $(c)$ to investigate whether the lack of platelets and (or) the highly purified antisera have an effect on re-endothelialization following endothelial removal; and $(d)$ to study the effect of thrombocytopenia and (or) antisera on the leukocyte count. 
CRUde ANTIPLATElet SERUM

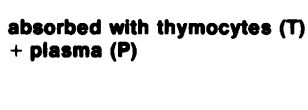

T + P-ABsorbed ANTIPLATELet SERUM
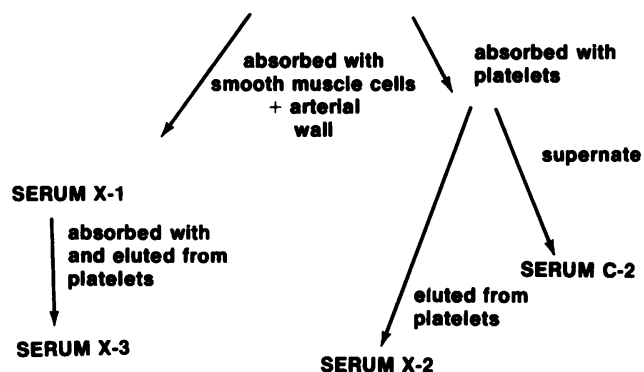

FIGURE 1 Antiplatelet serum purification. Flow sheet depicting treatment of C-APS to produce antiplatelet sera X-1, $\mathrm{X}-2$, and $\mathrm{X}-3$. Control serum $\mathrm{C}-2$ is the supernate collected after absorption of thymocyte and plasma-APS with platelets.

\section{METHODS}

A total of 239 male New Zealand white rabbits weighing between 2.2 and $3.0 \mathrm{~kg}$ were used. Each was screened for any obvious disease for 10 days before the initiation of experiments, and only healthy animals were used. They were housed singly in cages and fed a nonsupplemented rabbit chow diet ( $100 \mathrm{~g} /$ day) with water ad lib.

Preparation of antisera. Platelets were isolated from rabbit blood (7) and were washed twice in $\mathrm{pH} 6.2$ calciumfree Tyrode's buffer. $\cong 3 \times 10^{9}$ platelets were then suspended in $3.0 \mathrm{ml}$ of $\mathrm{pH} 7.35$ calcium-free Tyrode's buffer and were disrupted by sonication. This suspension was then emulsified in $3.0 \mathrm{ml}$ of Freund's complete adjuvant (Grand Island Biological Co., Grand Island, N. Y.) and was injected deep into intramuscular sites in the hind- and forelegs of a sheep. Subsequent booster injections of the same amount and preparation of platelets but without adjuvant were given weekly for 3 additional wk. Blood was collected, and serum was obtained 5 days after the final injection and was heat-inactivated for $45 \mathrm{~min}$ at $56^{\circ} \mathrm{C}$. Precipitated material was removed by centrifugation at $4,000 \mathrm{~g}$ for $10 \mathrm{~min}$. This serum was tested for its ability to produce thrombocytopenia in rabbits as previously described (6). Serum obtained from the blood of an untreated sheep was processed identically. These sera supernates were designated crude antiplatelet serum $(\mathrm{C}-\mathrm{APS})^{1}$ and crude normal sheep serum (C-NSS), respectively.

The C-APS and C-NSS were purified by multiple absorptions and elutions (Figs. 1 and 2). Lymphocytotoxicity of the crude sera, as measured by direct cytotoxic assay (8), was removed by absorption of $30 \mathrm{ml}$ of crude sera with $3 \times 10^{8}$ thymocytes isolated from rabbit thymus homogenates (6). The thymocyte-absorbed sera were tested for reactivity with arterial rabbit smooth muscle cells and endothelium by indirect tissue immunofluorescence (6) with transverse frozen sections of rabbit aorta overlaid with sheep-anti-rabbit plate-

${ }^{1}$ Abbreviations used in this paper: APS, antiplatelet serum; C-APS, crude antiplatelet serum; NSS, normal sheep serum; C-NSS, crude normal sheep serum. let serum or normal sheep serum and developed with fluorescein isothiocyanate-conjugated rabbit anti-sheep IgG. There was equivalent binding to cultured rabbit smooth muscle cells by both sera. However, thymocyte-absorbed C-APS showed a titer 16 times greater to endothelium than did the thymocyte-absorbed C-NSS. Binding to platelets was strongly positive with thymocyte-absorbed C-APS and negative with thymocyte-absorbed C-NSS. Both sera were further absorbed with normal rabbit serum $(0.05 \mathrm{ml} / \mathrm{ml}$ C-APS/CNSS) for $1 \mathrm{~h}$ at $22^{\circ} \mathrm{C}$ with constant agitation. They were then centrifuged at $30,000 \mathrm{~g}$ for $30 \mathrm{~min}$ at $4^{\circ} \mathrm{C}$, and the supernates were collected. Greater specificity was accomplished by three different methods.

(a) Thymocyte serum-absorbed C-APS and C-NSS were additionally absorbed with $5.0 \mathrm{ml}$ of packed cultured rabbit smooth muscle cells $/ 30 \mathrm{ml}$ of sera for $1 \mathrm{~h}$ at $22^{\circ} \mathrm{C}$ with constant sitrring and were subsequently centrifuged at $30,000 \mathrm{~g}$ for $30 \mathrm{~min}$ at $4^{\circ} \mathrm{C}$, and the supernates were retained. Each 30 $\mathrm{ml}$ aliquot of sera was then absorbed for $1 \mathrm{~h}$ at $22^{\circ} \mathrm{C}$ with constant agitation with a brei of $3.0 \mathrm{~g}$ of aortic intima and inner one-third of media which had been prepared by prior washings in 20:1 Sörensen-buffered $0.9 \% \mathrm{NaCl}$. These tissues and sera were centrifuged at $30,000 \mathrm{~g}$ for an additional $30 \mathrm{~min}$ at $4^{\circ} \mathrm{C}$, and the supernates were collected. The binding of these highly-absorbed sera (Fig. 1, serum X-1; Fig. 2, serum $\mathrm{C}-1$ ) with the arterial wall was examined again by indirect tissue immunofluorescence as above. All fluorescence was found to be removed with the exception of platelet reactivity which remained intact for serum X-1. These and all other sera were stored at $-70^{\circ} \mathrm{C}$.

(b) Thymocyte serum-absorbed C-APS and C-NSS were also purified by a modification of the digitonin-glycine elution technique of Kochwa and Rosenfeld (9). Platelets were prepared from syngeneic male New Zealand white rabbits. Blood was obtained by direct cardiac puncture and was anticoagulated by the addition of one part standard citratephosphorus-dextrose to nine parts of whole blood. The blood was centrifuged at $2,300 \mathrm{~g}$ for $3 \mathrm{~min}$ at $22^{\circ} \mathrm{C}$ to obtain platelet-rich plasma, from which the platelets were collected by additional centrifugation at $4,200 \mathrm{~g}$ for $10 \mathrm{~min}$ at $22^{\circ} \mathrm{C}$. Platelets were suspended in equal volumes of thymocyte

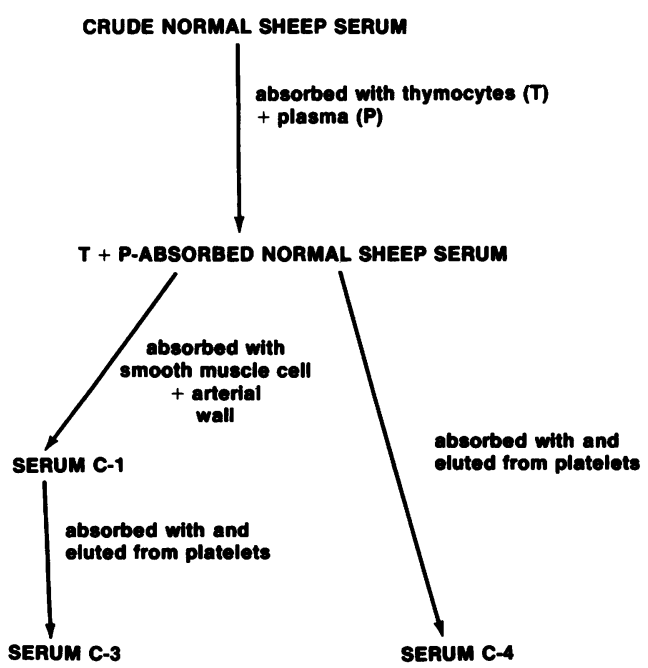

Figure 2 Normal sheep serum purification. Flow sheet depicting treatment of C-NSS to produce control sera C-1, C-3, and C-4. 
serum-absorbed C-APS or C-NSS and sensitized by constant agitation at $37^{\circ} \mathrm{C}$ for $1 \mathrm{~h}$. After sensitization, the platelets were lysed by the addition of $0.25 \%$ digitonin in buffered $0.9 \% \mathrm{NaCl}(1: 10 \mathrm{vol} / \mathrm{vol})$. The resultant stroma were centrifuged at $6,500 \mathrm{~g}$ for $5 \mathrm{~min}$ at $4^{\circ} \mathrm{C}$. The primary supernates, which were removed from the platelet pellets, were stored at $-70^{\circ} \mathrm{C}$ for further use. The sensitized platelet stroma i.e., C-APS- and C-NSS-incubated platelets, were resuspended and washed three times in $20 \mathrm{vol}$ of buffered $0.9 \% \mathrm{NaCl}$ at $4^{\circ} \mathrm{C}$. After the final wash, antibody elution was achieved by the addition of $2 \mathrm{vol}$ of buffered glycine, pH 3.0, to the washed stroma pellet. The individual eluates were dialyzed against $200 \mathrm{vol}$ of Sörensen's buffer for $24 \mathrm{~h}$ to remove any residual digitonin and to restore the $\mathrm{pH}$ to 7.4. Examination of the eluted platelet antiserum (X-2) and the identically-processed normal sheep serum (C-4) by indirect tissue immunofluorescence, showed no staining of either arterial smooth muscle cells or endothelium. Platelet reactivity of antiserum $X-2$ was intact, although somewhat less than for antiserum X-1. Serum C-4 displayed no platelet reactivity. Similar examination of the exhausted supernate (C-2) displayed modest staining of arterial smooth muscle cells and endothelium, but it did not stain rabbit platelets.

(c) Antiserum X-1 and serum C-1 were also purified by the modified digitonin-glycine elution technique. The multiply absorbed and eluted anti-serum (X-3) and similarly processed NSS (C-3) did not react by indirect tissue immunofluorescence with arterial smooth muscle cells or endothelium. However, anti-serum X-3 retained very strong reactivity for rabbit platelets.

Although cultured smooth muscle cells were used to partially purify the various antisera, the absence of antismooth muscle cell reactivity was investigated by the use of cross sections of arterial wall. This methodology was employed to circumvent the possibility of antigenic alteration which could conceivably occur in material from cell culture.

Titration of antibody effect; grouping of rabbits and injection regimen. Each APS (X-1, X-2, X-3) and each control NSS (C-1, C-2, C-3, C-4) were examined repeatedly in at least three different rabbits for dosage and their effect on platelet count, leukocyte count, and bleeding time. It was found that an intra-arterial injection of between 0.2 and $0.4 \mathrm{ml} / \mathrm{kg}$ body wt of sera X-1, X-2, or X-3 was needed to produce severe thrombocytopenia with resultant platelet counts of $<7,000 / \mathrm{cm}^{3}{ }^{3}$ These sera had negligible immediate effects on white cell counts, nor did they have an effect on the differential leukocyte count. The thrombocytopenia was accompanied by marked prolongation of the bleeding time. The control sera had no effect on platelet count, leukocyte count, including differential count, or bleeding time.

Several preliminary studies indicated that the time of administration of the APS had an effect on plaque formation following balloon de-endothelialization. It was found that arterial morphology 7 days after ballooning was different for animals given APS just before ballooning, as compared to rabbits given APS 2 or 3 days before ballooning and maintained thrombocytopenic. Animals given APS just before ballooning (10 $\mathrm{min}$ ) developed intimal thickening, although to a lesser extent than control animals; rabbits given APS 2-3 days before ballooning and maintained thrombocytopenic with daily injections of APS, failed to develop intimal thickening. Therefore, the injection schedule described below was followed.

Rabbits were divided into three groups, I, II, and III, corresponding to the type of serum given (Figs. 1 and 2) and were subdivided into five subgroups according to their time of sacrifice as shown in Table I. Each subgroup was given its appropriate serum daily for 3 days before balloon de-
TABLE I

Grouping of Rabbits

\begin{tabular}{llllllll}
\hline & & \multicolumn{4}{c}{$\begin{array}{c}\text { Time of sacrifice after } \\
\text { de-endothelialization }\end{array}$} \\
\cline { 3 - 7 } & Serum & & \multicolumn{4}{c}{ Days } \\
\cline { 4 - 7 } & given & $3 \mathrm{~h}$ & 3 & 7 & 14 & 28 \\
\hline
\end{tabular}

I

$\begin{array}{llllll}\text { Experimental } & \mathrm{X}-1 & (2)^{*} & (2) & (4) & (4) \\ \text { Control } & \mathrm{C}-1 & (2) & (2) & (4) & (4)\end{array}$

(4)

Control

(4)

II

$\begin{array}{lcccccc}\text { Experimental } & \mathrm{X}-2 & (3) & (3) & (5) & (5) & (5) \\ \text { Control } & \mathrm{C}-4 & (3) & (3) & (5) & (5) & (5) \\ & \mathrm{C}-2 & - & - & (3) & (3) & (3)\end{array}$

$\begin{array}{lllllll}\text { III } & & & & & & \\ \text { Experimental } & \mathrm{X}-3 & (2) & (2) & (5) & (5) & (5) \\ \text { Control } & \mathrm{C}-3 & (2) & (2) & (5) & (5) & (5)\end{array}$

* Numbers in parentheses denote the number of animals in each subgroup.

endothelialization, and twice daily thereafter, until sacrifice, to maintain a daily platelet count of $<7,000 / \mathrm{cm}^{3}$ in experimental groups. Animals were subjected to balloon injury and were sacrificed $3 \mathrm{~h}$ (subgroup A), 3 days (subgroup B), 7 days (subgroup $\mathrm{C}$ ), 14 days (subgroup $\mathrm{D}$ ), or 28 days (subgroup E) after de-endothelialization. In addition to the experimental and control pair-matched subgroups in groups I, II, and III, there was an additional, non-pair-matched control group (C-2). These animals were sacrificed at each of three times, namely, 7,14 , and 28 days after ballooning.

In addition to the 121 animals which comprised the study group, 68 rabbits (37 thrombocytopenic and 31 control) died during the course of the experiments from apparent anaphylaxis. These animals had severe difficulty in breathing within $5 \mathrm{~min}$ of the administration of the second or third serum injection with subsequent collapse and death. At necropsy, massive right heart dilatation, severe pulmonary congestion, and pulmonary edema were found. An additional 12 thrombocytopenic animals died 5-17 days after de-endothelialization from apparent exsanguination. The hematocrit in these animals ranged from 14 to $29 \% 1-2$ days before death, as compared with $35-49 \%$ before the experiment.

During the course of the experiments, 19 thrombocytopenic animals were found, $10 \mathrm{~min}$ after ballooning, to have platelet counts of $>7,000 / \mathrm{cm}^{3}$ These animals and their 19 control pair-mates were eliminated from the major study because we found, during pilot experiments, lesion formation in animals with platelet counts $\geq 7,000 / \mathrm{cm}^{3}$ Instead, they comprised a separate study group which was used to investigate a possible semiquantitative relationship between platelet number and lesion formation in endothelium-denuded animals. The data for these 19 experimental animals and their control pair-mates are shown in Table II. It is evident from the data that the 19 experimental animals with platelet counts $\geq 7,000 / \mathrm{cm}^{3} 10$ minutes after ballooning had a neointimal proliferation of 6-17 cell layers, compared with 0-3 cell layers at day 28 in all experimental animals with platelet counts of $<7,000 / \mathrm{cm}^{3} 10 \mathrm{~min}$ after ballooning.

In a separate experiment, 12 animals were studied to as- 
TABLE II

Lesion Formation in Animals with Platelet Counts $\geq 7,000$

\begin{tabular}{|c|c|c|c|c|c|c|c|}
\hline \multirow[b]{3}{*}{ Group } & \multirow{3}{*}{$\begin{array}{c}\text { Serum } \\
\text { given }\end{array}$} & \multicolumn{5}{|c|}{ Mean platelet count $\left(\right.$ per $\mathrm{cm}^{3}$ ) } & \multirow{3}{*}{$\begin{array}{l}\text { Extent of lesion } \\
28 \text { days after } \\
\text { ballooning } \\
\text { (range of number } \\
\text { of cell layers } \\
\text { blue \& non-blue) }\end{array}$} \\
\hline & & \multirow{2}{*}{$\begin{array}{c}\text { Before } \\
\text { administration } \\
\text { of sera }\end{array}$} & \multicolumn{4}{|c|}{ After ballooning } & \\
\hline & & & $10 \mathrm{~min}$ & $3 \mathrm{~h}$ & 7 days & 28 days & \\
\hline \multirow[t]{3}{*}{ Experimental } & $\mathrm{X}-1(6)^{*}$ & 316,600 & 17,200 & 10,200 & 6,800 & 6,500 & $8-17$ \\
\hline & $\mathrm{X}-2(6)$ & 317,200 & 18,600 & 14,000 & 7,300 & 6,000 & $6-14$ \\
\hline & $\mathrm{X}-3(7)$ & 355,000 & 13,800 & 9,600 & 6,400 & 5,500 & $6-12$ \\
\hline \multirow[t]{3}{*}{ Control } & $\mathrm{Cl}(6)$ & 324,000 & 335,000 & 309,000 & 300,000 & 320,000 & $9-20$ \\
\hline & C4 (6) & 320,000 & 327,000 & 313,500 & 325,000 & 335,000 & $10-24$ \\
\hline & C3 (7) & 365,400 & 350,000 & 360,000 & 375,500 & 365,000 & $11-21$ \\
\hline
\end{tabular}

* Numbers in parentheses denote the number of animals on which means are based.

certain the direct effects of thrombocytopenia and (or) APS/ NSS on the arterial wall. These animals were pair-matched, weighed, and divided into six groups of two rabbits each. They were not ballooned, but received daily injections of the sera X-1, X-2, or X-3 (group IV-A), and C-1, C-3, or C-4 (group IV-B), respectively. They were sacrificed 31 days after the initiation of the injection regimen.

Surgical procedure. Rabbits were anesthetized with intravenous pentobarbital sodium supplemented with ether, when necessary. Abdominal aortae and right iliac arteries of all animals were denuded of endothelium by passage of a 4 French Fogarty balloon catheter(Edwards Laboratories, Santa Ana, Calif.) according to a modification of the Baumgartner method (1). After ballooning, the catheter was withdrawn, the femoral artery was ligated, and the operative site was closed by traditional means. Operative bleeding was controlled by electrocautery.

Platelet counts, leukocyte counts, and bleeding times. Platelet counts (10) were performed on all animals before injection of the APS or NSS, $10 \mathrm{~min}$ after the injection of sera, before the insertion of the balloon catheter, 10 minutes after balloon catheterization, and daily thereafter until sacrifice.

Leukocyte cell counts were performed on a Coulter counter (Coulter Electronics, Hialeah, Fla.) in all rabbits at times corresponding to platelet counts. Differential leukocyte counts were performed before ballooning and before sacrifice.

Bleeding times of both experimental and control animals were assessed after the administration of the various sera. A disposable sterile lancet was used to make a 5-mm long, $0.25-\mathrm{mm}$ deep puncture in the external surface of the rabbit's ear. Freely flowing blood was gently blotted at 30 -s intervals, and the time was taken when the flow ceased.

Serum lipid measurements. Serum cholesterol and serum triglyceride levels were measured $(11,12)$ for two animal pairs selected at random from subgroup $A$, two animal pairs from subgroup $B$, three animal pairs from subgroup $C$, three animal pairs from subgroup $D$, and three animal pairs from subgroup E. Serum lipid measurements were made before injection of antisera/NSS and weekly thereafter until sacrifice. Animals from subgroups A, B, and C had serum lipid determinations before administration of sera and at the time of sacrifice.

Morphological techniques. Animals were sacrificed $3 \mathrm{~h}$, and $3,7,14$, and 28 days after endothelial denudation. $30 \mathrm{~min}$ before sacrifice, each animal received $5.0 \mathrm{ml}$ Evans blue dye intravenously $(13,14)$. Animals were given an overdose of pentobarbital sodium intravenously, and arterial perfusion at $100 \mathrm{mmHg}$ pressure was started immediately as previously described (1). Preparation of tissue for light and electron microscopy was performed on aortic tissue as previously published (1). After perfusion, the aorta was removed, carefully dissected free of adventitial fat, and opened longitudinally. It was then immersed in $0.1 \mathrm{M}$ cacodylatebuffered $2.5 \%$ gluteraldehyde- $2 \%$ paraformaldehyde (pH 7.4) and maintained at $22^{\circ} \mathrm{C}$ for $1 \mathrm{~h}$, followed by three washings in $0.1 \mathrm{M}$ cacodylate buffer, and was subsequently photographed as will be described. Eight standard transverse sections, approximately $5 \mathrm{~mm}$ in width, were taken from each aorta as follows: (a) $5 \mathrm{~mm}$ above the superior mesenteric artery (S-1); (b) $1 \mathrm{~mm}$ lateral to the ostia of the right renal artery (S-4); (c) $5 \mathrm{~mm}$ above the abdominal bifurcation (S-5); (d) $5 \mathrm{~mm}$ above the first intercostal arteries; $(e)$ left iliac artery, $5 \mathrm{~mm}$ below the aortic bifurcation; and $(f)$ right iliac artery, $5 \mathrm{~mm}$ below the aortic bifurcation. Sections designated S1-S5 were used for morphometrical analyses. All sections were placed in $7 \%$ sucrose- $0.1 \mathrm{M}$ cacodylate buffer overnight and processed for light and electron microscopy as previously described (1). Tranverse sections were cut about $1 \mu \mathrm{m}$ in thickness and stained for light microscopy with basic fuchsin-methylene blue (1). Each standard section (S1-S5) was evaluated for development of maximal and minimal number of cell layers of neointimal thickening. Ultrathin sections were prepared from standard areas of each thick section, stained with 6\% uranyl acetate followed by lead hydroxide, and examined with a Siemens 1A or 101 electron microscope (Siemens Corp., Medical/ Industrial Groups, Iselin, N. J.).

Extent of re-endothelialization. Photographs of gross specimens were taken with a Polaroid MP-4 camera (Polaroid Corp., Cambridge, Mass.) with a magnification of approximately three times normal size. Extent of re-endothelialization (non-blue areas after intravenous Evans blue dye) (13) was determined by tracing the stained and unstained areas on a sheet of exposed, developed X-ray film. The various areas were cut out and weighed. The weight of film was a measure of surface area of involvement by the re-endothelialized and not re-endothelialized regions. The extent of reendothelialization was determined by comparing the weight of the non-blued areas with the weight of the entire aorta, thus giving the percentage of aorta re-endothelialized.

Ouchterlony studies. Aliquots of serum from two pairgroups in each subgroup (B-E) of animals were tested for 


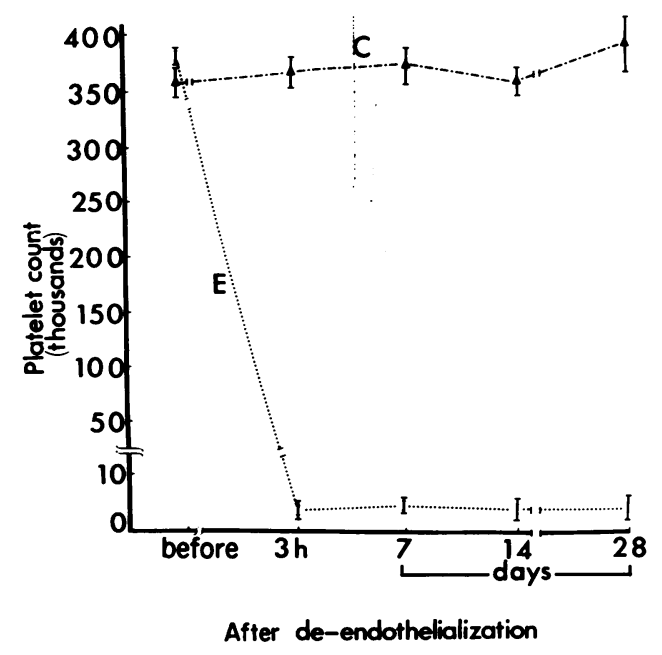

FIGURE 3 Mean platelet count in three experimental (E) and four control (C) groups at times corresponding to before the experiment, $3 \mathrm{~h}$, and 7,14 , and 28 days after balloon deendothelialization.

antibodies against NSS by the Ouchterlony technique. These aliquots were obtained immediately before administration of either APS or NSS and prior to sacrifice.

\section{RESULTS}

Cell counts and bleeding times. The mean platelet count for each of the three experimental and four control groups (I, II, including C-2, and III) is summarized in Fig. 3. The platelet counts were similar for experimental and control animals before the ballooning, but there were gross differences within $10 \mathrm{~min}$ after administration of APS. By day 4, the platelet count of the experimental (APS) animals was reduced to about $1 \%$ of the control (NSS) rabbits. This difference was maintained in those subgroups which were sacrificed at day 7,14 , or 28 after de-endothelialization.

The mean leukocyte count for each group is summarized in Fig. 4. There were no obvious systematic differences in these means, and the data are consistent with the hypothesis that the mean leukocyte count is unaffected by either APS or NSS.

The mean bleeding times for each of the three experimental groups are summarized in Fig. 5. These were similar for experimental and control animals before the ballooning, but there were gross differences 10 min after serum injection when the bleeding times for the experimental (APS) animals had increased more than 10-fold. This increase in bleeding time paralleled the reduction in platelet count and was seen at all time periods thereafter.

Serum lipids. The mean serum cholesterol levels for randomly selected pair-groups before the experiment in thrombocytopenic rabbits was $70 \mathrm{mg} / 100 \mathrm{ml}$, and

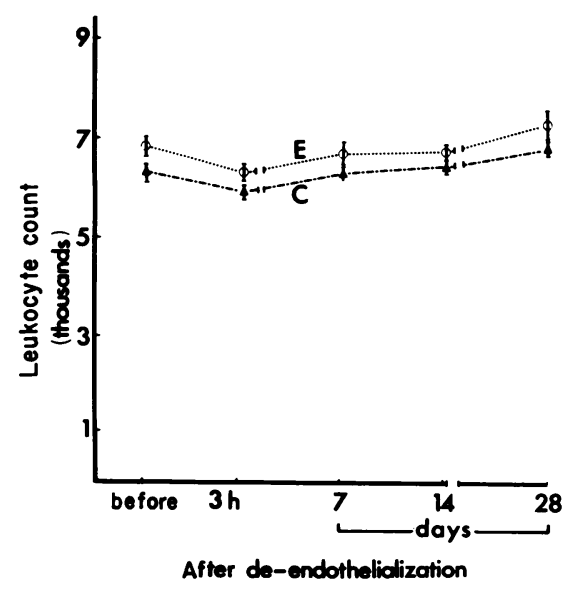

FIGURE 4 Mean leukocyte count in three experimental (E) and four control (C) groups at times corresponding to before the experiment, $3 \mathrm{~h}$, and 7,14 , and 28 days after balloon de-endothelialization.

$79 \mathrm{mg} / 100 \mathrm{ml} 7$ days, $73 \mathrm{mg} / 100 \mathrm{ml} 14$ days, and $72 \mathrm{mg} /$ $100 \mathrm{ml} 28$ days after de-endothelialization. Control rabbits had means serum cholesterol values of 66 $\mathrm{mg} / 100 \mathrm{ml}$ before the experiment, and $70 \mathrm{mg} / 100 \mathrm{ml} 7$ days, $66 \mathrm{mg} / 100 \mathrm{ml} 14$ days, and $57 \mathrm{mg} / 100 \mathrm{ml} 28$ days after de-endothelialization. The mean serum triglyceride values obtained before the study began were $86 \mathrm{mg} / 100 \mathrm{ml}$ in the experimental groups and $79 \mathrm{mg} / 100$ $\mathrm{ml}$ in control groups. There were no marked changes in serum triglyceride levels $3 \mathrm{~h}$, or $3,7,14$, or 28 days after ballooning in either experimental or control animals. Day 28 mean serum triglyceride levels were $80 \mathrm{mg} / 100 \mathrm{ml}$ in experimental and $85 \mathrm{mg} / 100 \mathrm{ml}$ in control groups.

Ouchterlony studies. Serum samples from rabbits which had received injections of either APS or NSS developed antibodies against NSS proteins as deter-

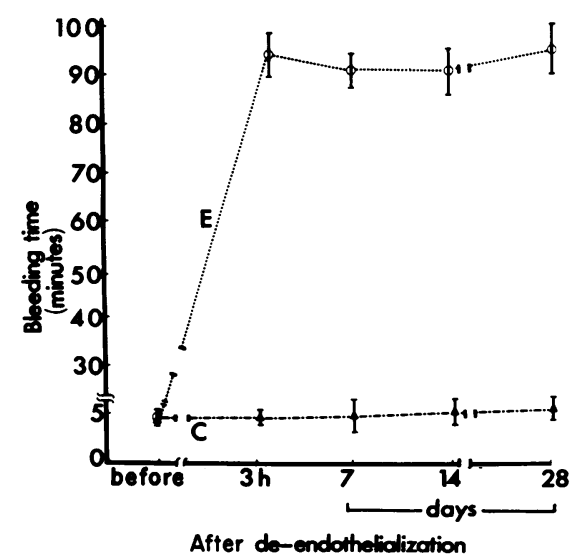

Figure 5 Mean bleeding time, in minutes, for three experimental (E) and control (C) groups. Bleeding times were determined $10 \mathrm{~min}$ before the initial injection of APS/NSS, $3 \mathrm{~h}$, and 7,14 , and 28 days after balloon injury. 


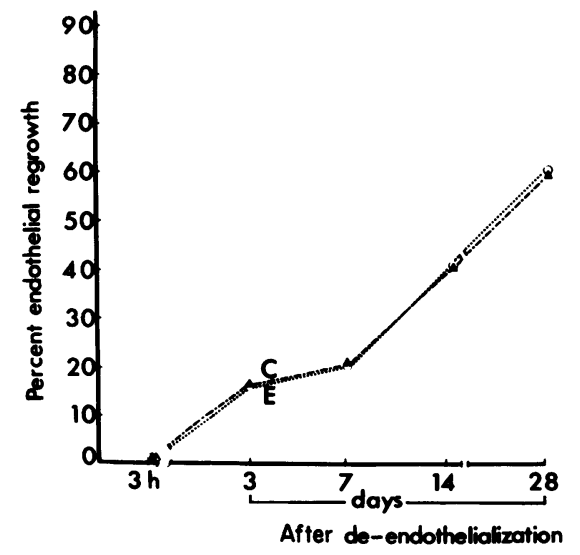

Figure 6 Percent endothelial regrowth in experimental group X-1 (E) and control groups C-1 and C-2 (C) $3 \mathrm{~h}, 3$, 7,14 , and 28 days after balloon injury.

mined by the Ouchterlony method; serum samples taken before injection of either serum yielded negative results in the Ouchterlony test.

Re-endothelialization: Evans blue dye permeability. The extent of re-endothelialization was not affected by the profound, prolonged thrombocytopenia. The results for subgroups X-1, C-1 (group I) and subgroup C-2 (group II) are shown in Fig. 6, which compares the percentage of blue and non-blue areas in these aortae; these results were comparable to those in all other groups. $3 \mathrm{~h}$ after ballooning, the entire abdominal aorta and ballooned iliac artery in both experimental and control animals appeared blue, indicating loss of endothelial covering (13). A tiny rim of non-blued area was barely visible around the lip of each branch orifice. 3 days after ballooning, the non-blued areas were seen as a thin rim around each vessel ostia. The abdominal aortae, in all groups, 7, 14, and 28 days after ballooning, showed a progressive diminution in the surface area of blue regions, with a concomitant increase in the surface area of non-blue regions. Re-endothelialization in pair-mates of experimental $(\mathrm{X}-1)$ and control (C-1) groups showed a significant correlation $(r=-0.98)$. A similar correlation was observed between pair-mates of groups X-2 and C-4, and $\mathrm{X}-3$ and C-3.

Macroscopic examination of the uninjured thoracic aorta and left iliac artery at all time periods and in all groups showed no staining with Evans blue dye. Macroscopic examination of the aorta and iliac arteries from all non-ballooned animals which received APS (group IV-A) or NSS (group IV-B) also showed no staining with Evans blue dye.

Morphology. Examination of the unballooned thoracic aorta and left iliac artery at all time periods showed normal arterial morphology by light and electron microscopy. The aorta and iliac arteries from non- ballooned rabbits given only APS (group IV-B) showed normal, intact vessels with a continuous endothelial cell lining.

$3 \mathrm{~h}$ and 3 days after ballooning, platelets were seen by both light and electron microscopy to be covering the denuded intimal surface in all control animals as has been previously described $(15,16)$. Thrombocytopenic rabbits showed no, or very few, platelets on the denuded intimal surface. No morphological evidence of medial injury, as manifest by cell necrosis or leukocyte migration, was seen in either experimental or control animals.

7 days after endothelial denudation, the blue areas of control animals were found to have a mean neointimal proliferation of 3.5 cell layers. Platelets were observed adherent to the lumenal surface in these regions. Non-blue previously ballooned regions

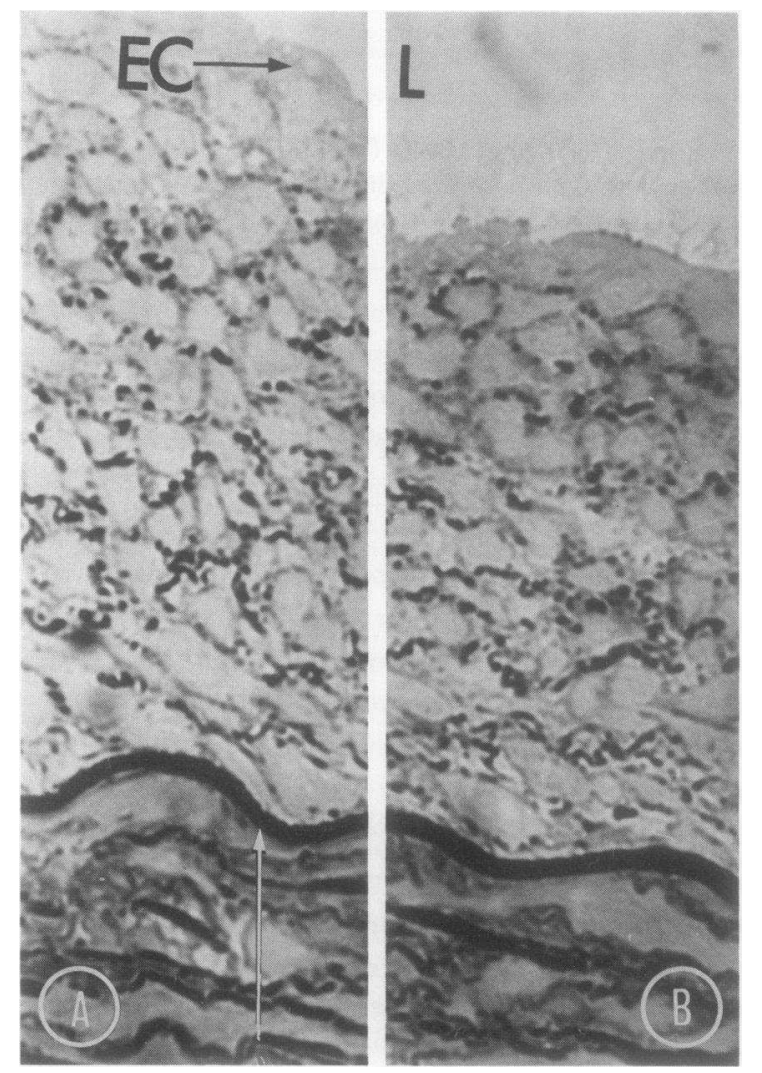

FIGURE 7 Blue and non-blue regions 28 days after balloon injury. This composite photomicrograph of a blue region (B) and a non-blue region (A) taken from an animal receiving NSS shows a markedly thickened neointimal proliferation. The internal elastic lamina (arrow) is seen along the lower portion of the picture. The lumen $(L)$ of the aorta is seen at the top of the picture. Often seen were platelets adherent to, and erythrocytes associated with, the lumenal surface in blue areas. A covering layer of endothelial cells (EC) was seen in nonblue regions. Basic fuchsin-methylene blue. Original magnification $\times 400$. 
showed an intact endothelial cell layer overlying a thickened intima with a mean neointimal proliferation of 2.3 cell layers. No formed elements of the blood were observed in these regions. Thrombocytopenic animals showed no neointimal thickening in either blue or non-blue previously ballooned regions. No medial injury was seen in either control or experimental animals.

14 days after endothelial denudation, blue regions of control animals showed a mean neointimal smooth muscle cell proliferation of 9.5 cell layers. Platelets were seen adherent to the lumenal surface in these regions. Non-blue previously ballooned areas showed an endothelial cell covering layer overlying a mean smooth muscle cell neointimal proliferation of 6.3 cell layers. Once again, no formed elements of the blood were seen in these areas. Thrombocytopenic animals continued to show a lack of neointimal proliferation. Blue regions showed a generally denuded intimal surface with no, or very few, platelets adherent. The mean smooth muscle cell proliferation in blue regions was 0.53 cell layers. Non-blue previously ballooned regions had an intact monolayer of endothelium with no underlying intimal proliferation. The control animals showed no morphological evidence of medial injury, but the thrombocytopenic animals manifested separation of the medial smooth muscle cells by edema fluid. No morphological evidence of cell death was seen.

28 days after ballooning, blue areas from control animals showed marked neointimal smooth muscle cell proliferation (Fig. 7B) with a mean of 18.2 cell layers. Platelets, although much fewer in number, continued to be present scattered on the lumenal surface. Non-blue previously ballooned regions (Fig. 7A) showed an intact endothelial cell layer overlying a markedly thickened neointima. The mean smooth muscle cell proliferation was $\mathbf{1 3 . 1}$ cell layers. Thrombocytopenic animals showed no, or very minimal, neointimal proliferation in blue regions (Fig. 8) by both light and electron microscopy (Fig. 9). The mean smooth muscle cell proliferation was 1.0 cell layers. No platelets were observed adherent to the lumenal surface. In non-blue previously ballooned areas, an intact monolayer of endothelium overlying the internal elastic lamina was seen (Fig. 10). There was no, or very minimal, underlying neointimal proliferation. The mean smooth muscle cell proliferation was 0.5 cell layers. Electron microscopy confirmed these findings. (Fig. 11). Control animals continued to show no evidence of medial injury. Thrombocytopenic animals manifested medial edema without frank necrotic changes.

The data relating to the mean number of cell layers in groups I, II, and III of animals are shown graphically in Figs. 12 and 13. The three normal sheep sera did not affect the normal proliferative process after endothelial injury; there was a consistent increase in the number of cell layers in each of the five anatomical areas in the control animals at day $7(P<0.01)$, and there were additional increases 14 and 28 days after ballooning. The results for the control animals were

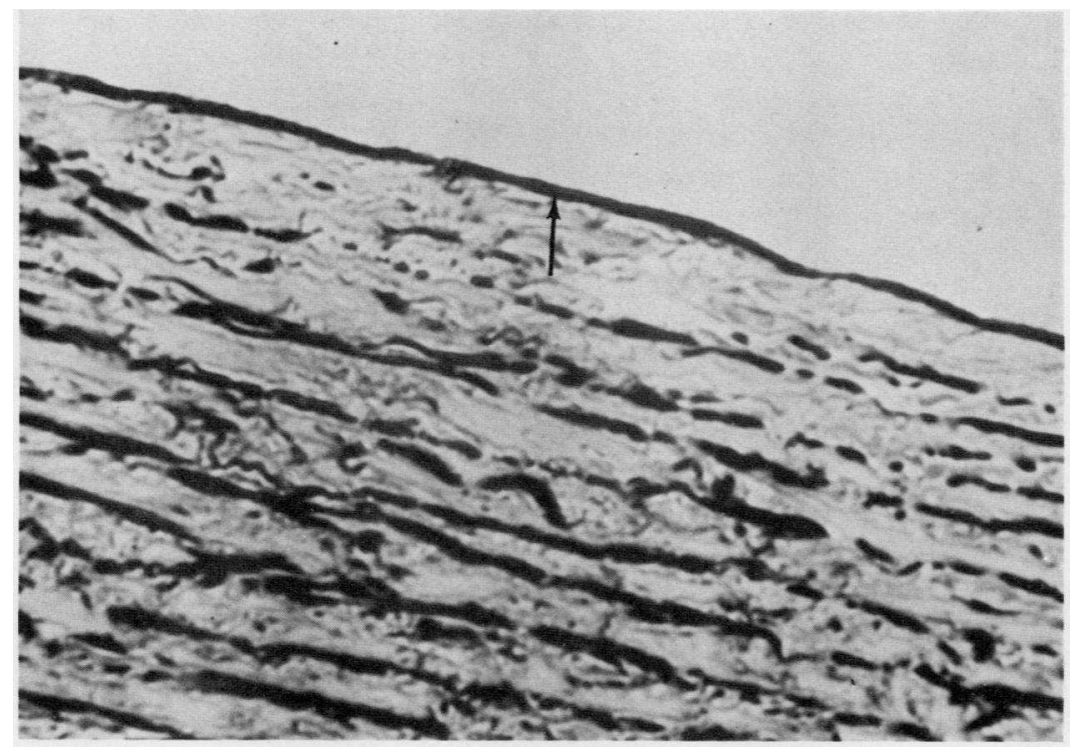

FIGURE 8 Blue region in a thrombocytopenic animal 28 days after balloon injury. This photomicrograph of a blue region taken from an animal receiving APS shows a naked internal elastic lamina (arrow) with no overlying neointimal proliferation. Basic fuchsin-methylene blue. Original magnification $\times \mathbf{4 0 0}$. 


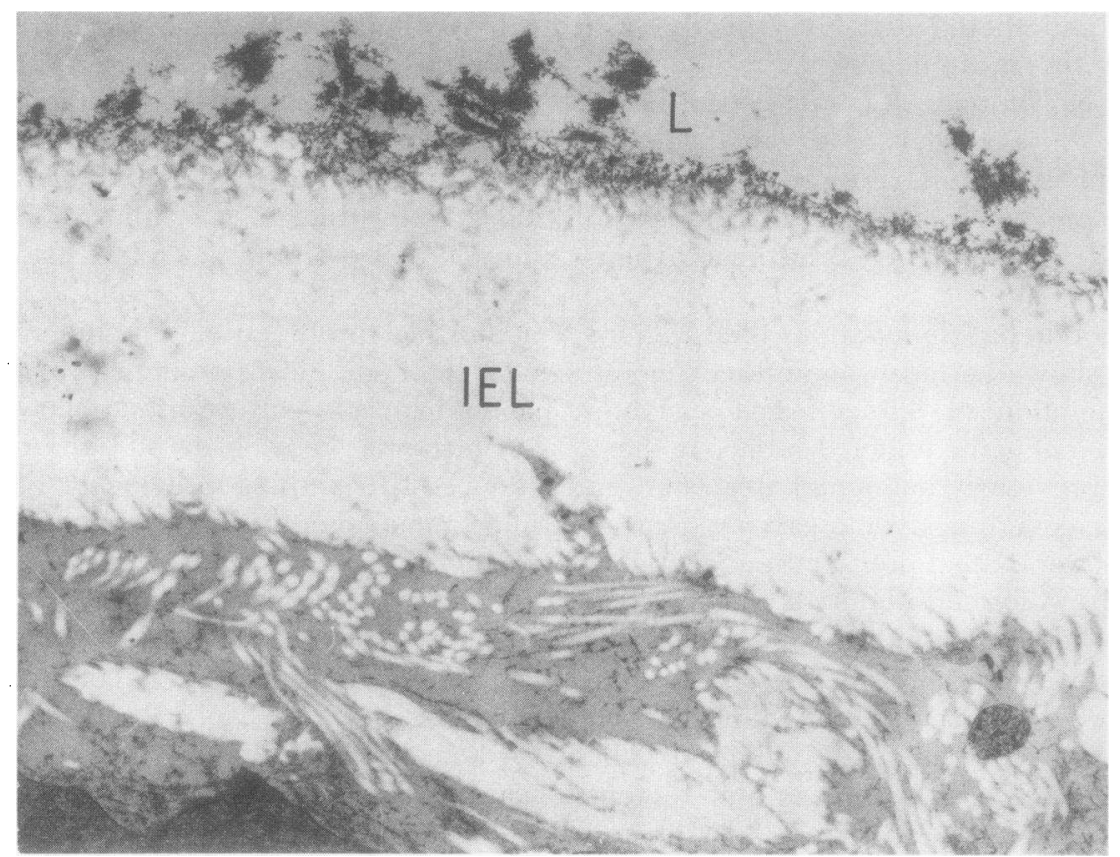

FiguRE 9 Blue region in a thrombocytopenic animal 28 days after balloon injury. This electron micrograph of the same blue region shown in Fig. 8 shows a naked internal elastic lamina (IEL). There is no overlying neointimal thickening. The lumen $(\mathrm{L})$ of the artery is seen along the top of the picture. Original magnification $\times 7,800$.

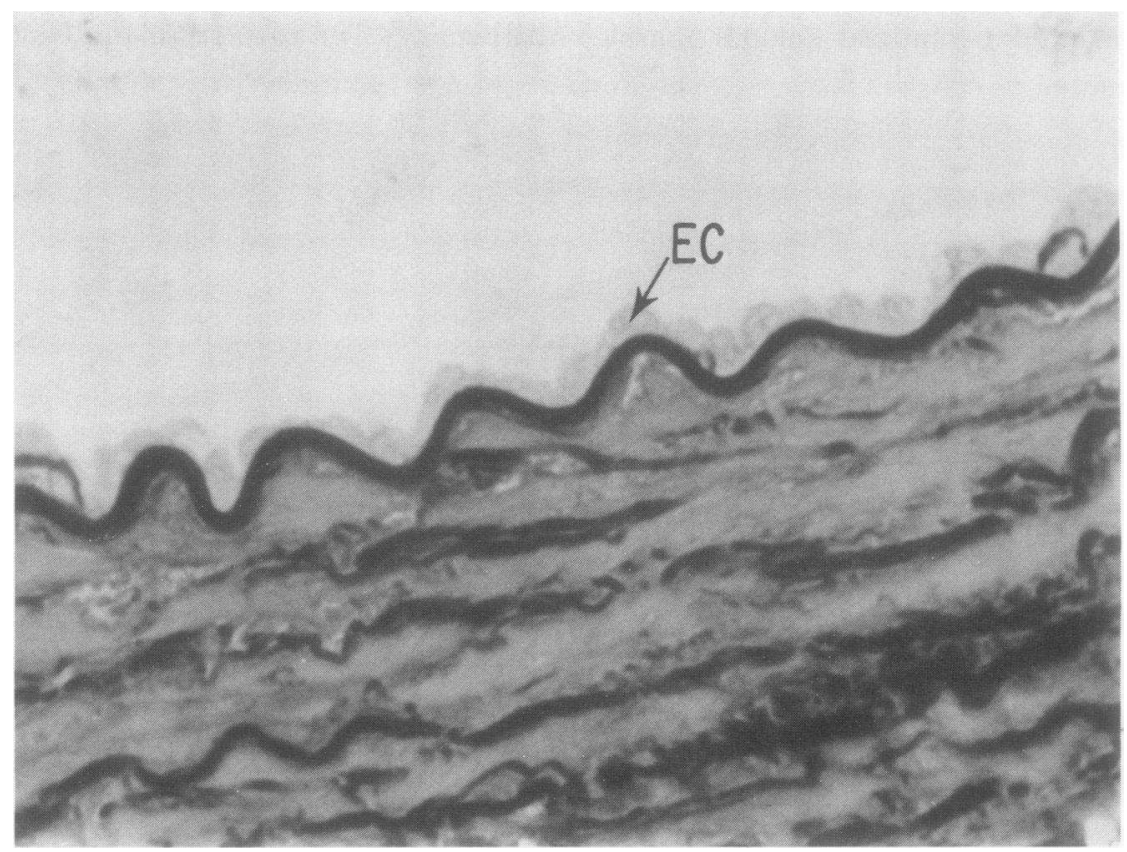

FIGURE 10 Non-blue region in a thrombocytopenic animal 28 days after balloon injury. This photomicrograph of a non-blue region taken from an animal receiving APS shows an intact monolayer of endothelial cells (EC) overlying the internal elastic lamina. No underlying neointimal thickening is seen. Basic fuchsin-methylene blue. Original magnification $\times 400$. 


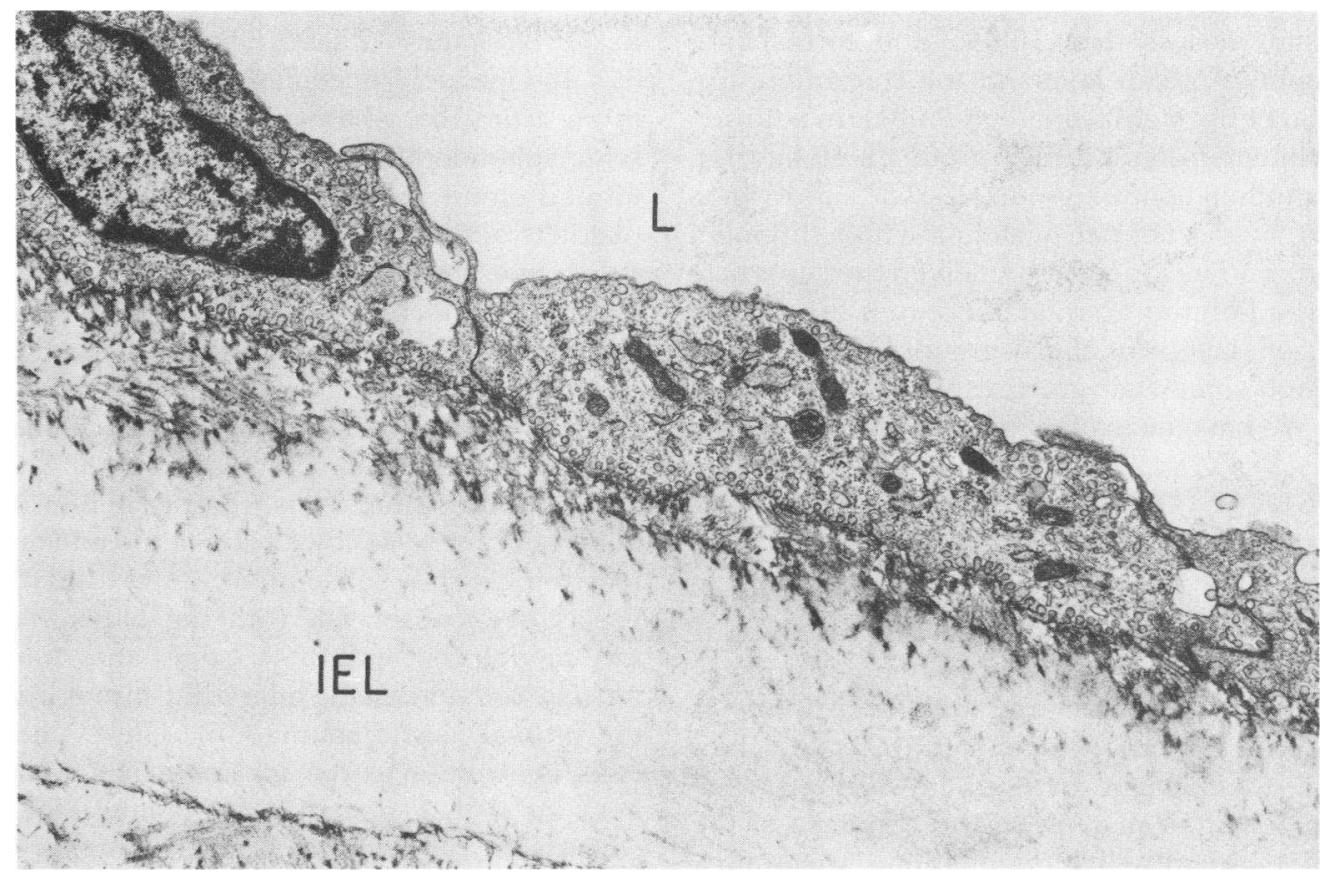

Figure 11 Non-blue region in a thrombocytopenic animal 28 days after balloon injury. The electron micrograph of the same non-blue region shown in Fig. 10 shows a layer of endothelial cells overlying the internal elastic lamina (IEL). The lumen (L) is seen on the top of the micrograph. Original magnification $\times 7,800$.

comparable from one experiment to another. The numbers of cell layers in the three different blue areas (S1, S3, and S5) were very similar to each other at each of the different times of assessment. Similarly, the numbers of cell layers in the two nonblue previously ballooned areas (S2 and S4) were comparable. The maximum numbers of cell layers in the blue areas were consistently higher than in the nonblue previously ballooned areas in all control animals $(P<0.001)$. There are interesting differences between blue and non-blue previously ballooned

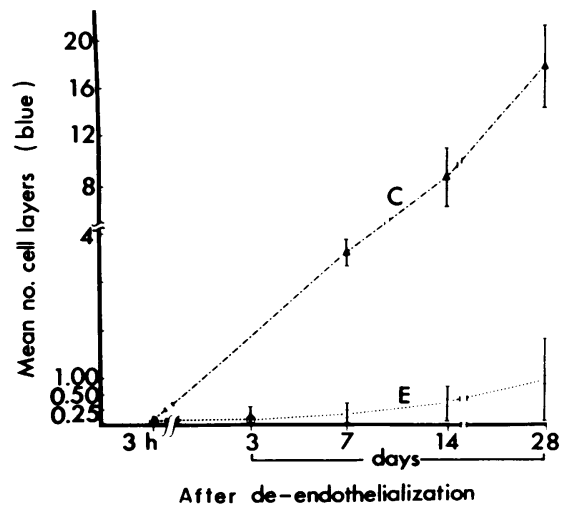

Figure 12 Mean number of cell layers (blue regions) in three experimental (E) groups (I, II, and III) and three control (C) groups (I, II, and III). regions for thrombocytopenic animals. In the non-blue previously ballooned areas among thrombocytopenic animals in subgroups $\mathrm{C}, \mathrm{D}$, and $\mathrm{E}$, there are no differences in the mean number of cell layers, all of which are markedly less than the corresponding means in the control group $(P<0.001)$. However, there is a statistically significant increase in the mean number of cell layers in the blue areas among thrombocytopenic animals 14 days compared with 7 days after ballooning, and in animals 28 days after ballooning compared with rabbits 14 days after ballooning $(P$

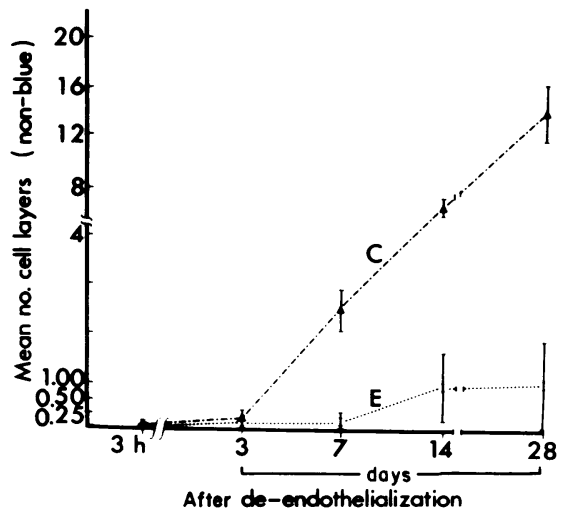

Figure 13 Mean maximal number of cell layers (non-blue regions) in three experimental (E) groups (I, II, and III) and three control (C) groups (I, II, and III). 
$<0.001)$. It is important to note that despite these differences the mean number of cell layers in experimental animals is less than $10 \%$ of the corresponding mean number of cell layers in the control groups, this reduction being significant $(P<0.001)$. In addition to the experiments reported from groups I, II, and III, there was another control group, C-2 (a subdivision of group II) that was not pair-matched with a thrombocytopenic group. These animals received the supernate of the absorbed-eluted antiplatelet serum. The mean number of cell layers in these groups of animals is similar, though somewhat greater than the other control groups. We have no explanation for this difference.

\section{DISCUSSION}

The findings presented in this study indicate that the fibromusculoelastic lesion which develops as the arterial response to a single endothelial injury in rabbits is inhibited in severely thrombocytopenic animals. Inasmuch as the method of producing such injury is identical in both thrombocytopenic animals and their nonthrombocytopenic pair-mates, the results implicate the importance of the platelet in the response of the arterial wall to endothelial denudation. Apparently, neither the various antiplatelet sera and their resultant thrombocytopenic state, nor the normal sheep sera had any direct deleterious effect on the intact aortic or iliac arterial wall. This fact is evidenced by the normal morphology and ultrastructure after 31 days of injections of these sera in non-ballooned animals. We cannot state with certainty that the highly purified preparations of platelet antisera used in this study do not share cross reactivity with other antigenic determinants which may play a role in fibromusculoelastic lesion formation. However, such additional specificities could not be demonstrated by indirect immunofluorescence against various elements of the arterial wall. Accordingly, the role of cross reactivity is not presently a serious contradiction to the concept that sustained thrombocytopenia itself, and not antibody action other than one directed towards platelets, is implicated in the observed phenomenon of suppression of smooth muscle cell proliferation.

The inhibition of plaque formation was related to the degree of thrombocytopenia. Thrombocytopenic levels $<7,000 / \mathrm{cm}^{3}$ were necessary to inhibit smooth muscle cell lesion formation. Animals with platelet counts $\$ 7,000 / \mathrm{cm}^{3}$ were found to develop intimal thickening. Thus, there was an apparent quantitative relationship between circulating platelet number and the response of the arterial wall to a single intimal injury.

A long standing hypothesis of atherosclerosis (17) which has recently received considerable attention is that endothelial injury initiates a series of steps that leads to medial smooth muscle cell migration and proliferation $(2,15,16,18-28)$ characteristic of the arterio- sclerotic lesions. Several variations of the endothelial injury hypothesis have been a topic of intensive study in our laboratory $(21,22,29)$ and those of others $(30-$ 34). It is widely accepted that de-endothelialization of an artery by whatever means exposes the underlying subendothelial connective tissues to the various formed elements of the blood, notably platelets. The platelets adhere to the subendothelial connective tissues, undergo the release reaction and aggregate $(35,36)$. It has been postulated $(2,5,6,37)$ that this interaction of "platelet factors," as well as possibly other plasma constituents such as low density lipoproteins (38-40) and insulin (41) leads to intimal migration of medial smooth muscle cells and their subsequent proliferation. Thus, the disruption of the intact endothelium is followed by a postulated "platelet reaction" with a subsequent "myocellular response." It has been observed, with the balloon catheter injury model, that within 4-7 days after injury, smooth muscle cells are seen migrating through fenestrae in the intimal elastic lamina (16). These smooth muscle cells contribute to the increase in neointimal thickness so that $1 \mathrm{mo}$ after ballooning, the neointima consists of between 15 and 25 smooth muscle cell layers with interposed connective tissue.

The findings presented in the present study show that $(a)$ the smooth muscle cell proliferation and intimal thickening seen after endothelial removal is markedly inhibited if the animals are thrombocytopenic before balloon catheter endothelial injury; $(b)$ this inhibition does not appear to be due to an effect of the antisera on smooth muscle cell proliferation; $(c)$ the thrombocytopenia and (or) the antisera do not appear to affect re-endothelialization; $(d)$ leukocyte counts were apparently not obviously affected, supporting the conclusion that the inhibition of smooth muscle cell proliferation is mainly attributable to the low platelet counts.

In conclusion, the results of this study lend support to the importance of the platelet in what is probably a key event in atherogenesis, the smooth muscle cell proliferative response following arterial intimal injury.

\section{ACKNOWLEDGMENTS}

The authors gratefully acknowledge Ms. Maria Underwood and Ms. Carmel DeDeo for typing this manuscript.

This work was supported by National Institutes of Health grant HL 16387.

\section{REFERENCES}

1. Spaet, T. H., M. B. Stemerman, F. J. Veith, and I. Lejnieks. 1975. Intimal injury and regrowth in the rabbit aorta: medial smooth muscle cells as a source of neointima. Circ. Res. 36: 58-70.

2. Ross, R., and J. S. Glomset. 1973. Atherosclerosis: A problem in the biology of the arterial smooth muscle cell. Science (Wash. D. C.). 180: 1332-1335.

3. Arteriosclerosis. Report by National Heart and Lung In- 
stitute Task Force Arteriosclerosis. PHEW. Publication No. 72-219, 13, 1972.

4. Geer, J. C., and M. D. Haust. 1972. Monograph on atherosclerosis. S. Karger AG., Basel.

5. Ross, R., J. Glomset, B. Kariya, and L. Harker. 1974. A platelet-dependent serum factor that stimulates the proliferation of arterial smooth muscle cells in vitro. Proc. Natl. Acad. Sci. 71: 1207-1211.

6. Moore, S., R. J. Friedman, D. P. Singal, J. Gauldie, M. Blajchman, and R. S. Roberts. 1976. Inhibition of injuryinduced thromboatherosclerotic lesions by antiplatelet serum in rabbits. Thromb. Haemostasis. 1: 70-81.

7. Ardlie, N. G., M. A. Packham, and J. F. Mustard. 1970. Adenosine diphosphate induced platelet aggregation in suspensions of washed rabbit platelets. Br. J. Haematol. 19: 7-17.

8. Mittal, K. K., M. R. Mickey, D. P. Singal, and P. I. Terasaki. 1968. Serotyping for homotransplantation. XVIII. Refinement of microdroplet lymphocyte cytotoxicity test. Transplantation (Baltimore). 6: 913-927.

9. Kochwa, S., and R. Rosenfeld. 1964. Immunological studies of the Rh system. J. Immunol. 92: 682-701.

10. Brecher, G., and E. P. Cronkite. 1950. Morphology and enumeration of human blood platelets. J. Appl. Physiol. 3: 365-377.

11. Block, W. D., K. J. Jarret, and J. B. Levine. 1966. An improved automated determination of serum total cholesterol with a single color reagent. Clin. Chem. 12: 681689.

12. Noble, R. P., and F. M. Campbell. 1970. Improved accuracy in automated fluorometric determination of plasma triglycerides. Clin. Chem. 16: 166-170.

13. Stemerman, M. B., T. H. Spaet, F. A. Pitlick, J. R. Cintron, I. Lejnieks, and M. L. Tiell. 1977. Intimal healing: the pattern of re-endothelialization and intimal thickening. Am. J. Pathol. 87: 125-137.

14. Stemerman, M. B., F. A. Pitlick, and H. B. Dembitzer. 1976. Electron microscopic immunohistochemical identification of endothelial cells in the rabbit. Circ. Res. 38: 58-70.

15. Stemerman, M. B. 1973. Thrombogenesis of the rabbit arterial plaque. An electron microscopic study. Am. J. Pathol. 73: 7-18.

16. Stemerman, M. B., and R. Ross. 1972. Experimental arteriosclerosis. I. Fibrous plaque formation in primates, an electron microscopic study. J. Exp. Med. 136: 769789.

17. Virchow, R. 1856. Phlogose and Thrombose in Gefässsystem. In Gesammelte Abhandlungen zur Wissenshafflichen Medicin. Meidinger, Sohn and Co., Frankfurtam-Main. 458-636.

18. Baumgartner, H. R., and A. Studer. 1966. Folgen des Gefässkatheterismus am normo-und hypercholesterinaemischen Kaninchen. Pathol. Microbiol. 29: 393-405.

19. Bjorkerud, S. 1969. Reaction of the aortic wall of the rabbit after superficial longitudinal, mechanical trauma. Virchows Arch. Abt. A Pathol. Anat. 347: 197-210.

20. Baumgartner, H. R. 1973. The role of blood flow in platelet adhesion, fibrin deposition, and formation of mural thrombi. Microvasc. Res. 5: 167-179.

21. Moore, S. 1973. Thromboatherosclerosis in normolipemic rabbits. A result of continued endothelial damage. Lab. Invest. 29: 478-487.

22. Friedman, R. J., S. Moore, and D. P. Singal. 1975. Repeated endothelial injury and induction of atherosclerosis in normolipemic rabbits in human serum. Lab. Invest. 30: 404-415.

23. Harker, L., S. Slichter, C. R. Scott, and R. Ross. 1974. Homocystinemia: vascular injury and arterial thrombosis. N. Engl. J. Med. 291: 537-543.
24. Wight, T. N., and R. Ross. 1975. Proteoglycans in primate arteries. I. Ultrastructural localization and distribution in the intima. J. Cell Biol. 67: 660-674.

25. Webster, W. S., S. P. Bishop, and J. C. Geer. 1974. Experimental aortic intimal thickening. I. Morphology and source of intimal cells. Am. J. Pathol. 76: 245260.

26. Fishman, J. A., G. B. Ryan, and M. J. Karnovsky. 1975. Endothelial regeneration in the rat carotid artery and the significance of endothelial denudation in the pathogenesis of myointimal thickening. Lab. Invest. 32: 339351.

27. Bjorkerud, S., and G. Bondjers. 1971. Arterial repair and atherosclerosis after mechanical injury. II. Tissue response after induction of a total local necrosis (deep) longitudinal injury. Atherosclerosis. 14: 259-276.

28. Poole, J. C. F., S. B. Cromwell, and E. P. Benditt. 1971. Behavior of smooth muscle cells and formation of extracellular structures in the reaction of extracellular structures in the reaction of arterial walls to injury. Am. J. Pathol. 62: 391-404.

29. Friedman, R. J., S. Moore, D. P. Singal, and M. Gent. 1976. Regression of injury-induced atheromatous lesions in rabbits. Arch. Pathol. Lab. Med. 100: 189-195.

30. Mustard, J. F., and M. A. Packham. 1975. The role of blood and platelets in atherosclerosis and the complications of atherosclerosis. Thromb. Diath. Haemorrh. 33: 444-456.

31. French, J. E. 1966. Atherosclerosis in relation to the structure and function of the arterial intimal, with special reference to the endothelium. Int. Rev. Exp. Pathol. 5: 253-353.

32. Minick, C. R., G. E. Murphy, and W. G. Campbell, Jr. 1966. Experimental induction of athero-arteriosclerosis by the synergy of allergic injury to arteries and lipid rich diet. I. Effect of repeated injections of horse serum in rabbits fed a dietary cholesterol supplement. J. Exp. Med. 124: 635-652.

33. Minick, C. R., and G. E. Murphy. 1973. Experimental induction of atheroarteriosclerosis by the synergy of allergic injury to arteries and lipid rich diet. II. Effect of repeated injections of horse serum in rabbits fed a lipid rich, cholesterol-poor diet. Am. J. Pathol. 73: 265300.

34. Hardin, N. J., C. R. Minick, and G. E. Murphy. 1973. Experimental induction of athero-arteriosclerosis by the synergy of allergic injury to arteries and lipid-rich diet. Am. J. Pathol. 73: 301-322.

35. Mustard, J. F., and M. A. Packham. 1970. Factors influencing platelet function: adhesion, release and aggregation. Pharmacol. Rev. 22: 97-187.

36. Weiss, H. J. 1975. Medical progress. Platelet physiology and abnormalities of platelet function. N. Engl. J. Med. 293: 531-541, 580-588.

37. Ross, R., and J. A. Glomsett. 1976. The pathogenesis of atherosclerosis. New Engl. J. Med. 295: 369-377.

38. Bierman, E. L., O. Stein, and Y. Stein. 1974. Lipoprotein uptake and metabolism by rat aortic smooth muscle cells in tissue culture. Circ. Res. 35: 136-150.

39. Bierman, E. L., S. Eisenberg, O. Stein, and Y. Stein. 1973. Very low density lipoprotein "remnant" particles: uptake by aortic smooth muscle cells in culture. Biochim. Biophys. Acta. 329: 163-169.

40. Bierman, E. L., and J. J. Albers. 1975. Lipoprotein uptake by cultured human arterial smooth cells. Biochim. Biophys. Acta. 388: 198-202.

41. Stout, R. W., E. L. Bierman, and R. Ross. 1975. Effect of insulin on the proliferation of cultured primate arterial smooth muscle cells. Circ. Res. 36: 319-327. 